\title{
Photosynthesis and daily metabolic carbon balance of the invasive Caulerpa racemosa var. cylindracea (Chlorophyta: Caulerpales) along a depth gradient
}

\author{
JAIME BERNARDEAU-ESTELLER ${ }^{1,2}$, LÁZARO MARÍN-GUIRAO $^{1}$, \\ JOSE M. SANDOVAL-GIL ${ }^{1,2}$ and JUAN M. RUIZ ${ }^{1}$ \\ ${ }^{1}$ Instituto Español de Oceanografía, Centro Oceanográfico de Murcia, Seagrass Ecology Group, C/ Varadero, 1. \\ 30740 San Pedro del Pinatar, Murcia, Spain. E-mail: juanm.ruiz@mu.ieo.es \\ ${ }^{2}$ Departamento de Ciencias del Mar y Biología Aplicada, Universidad de Alicante.
}

SUMMARY: The photosynthetic plasticity of the invasive green alga Caulerpa racemosa v. cylindracea (hereafter $C$. racemosa) has been proposed as a relevant mechanism determining its successful performance on Mediterranean benthic assemblages over broad depth gradients. In the present study, the photosynthetic performance of $C$. racemosa was evaluated through a carbon balance approach at three invaded sites with contrasting depths (11, 18 and $26 \mathrm{~m})$ and light regimes. At each sampling depth, photosynthesis vs irradiance ( $\mathrm{P}$ vs $\mathrm{E}$ ) curves were performed on $C$. racemosa fronds and daily net productivity values were obtained by the numerical integration of $\mathrm{P}$ vs $\mathrm{E}$ models with continuous recording of irradiance measured on the sea floor. Photosynthetic responses were consistent with those typically exhibited by shade-adapted macroalgal species and other Mediterranean populations of $C$. racemosa: a significant reduction in maximum photosynthesis $\left(\mathrm{P}_{\max }\right)$ occurring at an intermediate depth $(18 \mathrm{~m})$ and a higher photosynthetic efficiency $(\alpha)$ and lower dark respiration rate $\left(\mathrm{R}_{\mathrm{d}}\right)$ at the deepest sampling depth. Mean values of daily net $\mathrm{C}$ balance obtained from the deeper site were only $15 \%$ lower than those obtained from the shallower site, despite the severe reduction in light availability. This daily net carbon gain was $c a$. $29 \%$ higher than would be expected if photosynthetic adjustments did not occur in the deeper algal population. The evidence provided by these data support the hypothesis of photoacclimation in $C$. racemosa as an effective mechanism to optimize algal productivity across depth gradients in the Mediterranean Sea.

Keywords: Caulerpa racemosa, carbon balance, invasive species, photosynthesis, depth, Mediterranean.

RESUMEN: Fotosíntesis Y BALANCE METABÓlico DiARIO DE CARBONO DEL ALGA INVASORA CAULERPA RACEMOSA VAR. CYLINDRACEA (CLHOROPHYTA: CAULERPACEAE) A LO LARGO DE UN GRADIENTE DE PROFUNDIDAD. - La plasticidad fotosintética del clorófito Caulerpa racemosa v. cylindracea (C. racemosa a partir de ahora) es considerado uno de los principales mecanismos determinantes de su éxito invasor en las comunidades bentónicas del Mediterráneo. En el presente estudio se evalúa la capacidad fotosintética de $C$. racemosa mediante una aproximación basada en el balance de carbono, en tres localidades invadidas con profundidad $(11,18$ y $26 \mathrm{~m})$ y régimen lumínico bien diferenciados. En cada profundidad, se realizaron curvas Fotosíntesis vs Irradiancia (F vs I) con frondes del alga y se estimó la productividad neta diaria mediante la integración numérica de los modelos F vs I con registros en continuo de irradiancia PAR incidente sobre el fondo. Las respuestas fotosintéticas fueron consistentes con las descritas en macroalgas adaptadas a ambientes poco iluminados, así como con las mostradas en otras poblaciones mediterráneas de C. racemosa: reducción significativa de la fotosíntesis máxima $\left(\mathrm{P}_{\max }\right)$ a profundidades intermedias $(18 \mathrm{~m})$, y una mayor eficiencia fotosintética $(\alpha)$ y menor tasa de respiración en la oscuridad $\left(\mathrm{R}_{\mathrm{d}}\right)$ en la localidad más profunda. Los valores medios del balance de C en la estación más profunda fueron solo un $15 \%$ más bajo que los obtenidos en la más somera, a pesar de la severa reducción de la disponibilidad de luz. Esta ganancia neta diaria de C fue un $29 \%$ más elevada que los valores esperados si se hubieran producido los ajustes fotosintéticos descritos en la población profunda. La evidencia aportada apoya la hipótesis de fotoaclimatación en $C$. racemosa como mecanismo efectivo para optimizar la productividad algal a lo largo de gradientes de profundidad en el Mediterráneo.

Palabras clave: Caulerpa racemosa, balance de carbono, especies invasoras, fotosíntesis, profundidad, Mediterráneo. 


\section{INTRODUCTION}

The Mediterranean Sea harbours the greatest number of exotic species of macrophytes in the world, with nine species of macroalga identified as invaders with a high potential capacity to cause harmful effects on native benthic communities (Boudouresque and Verlaque, 2002). Of these species, the introduced green alga Caulerpa racemosa var. cylindracea (hereafter $C$. racemosa) has spread extensively throughout almost the whole Mediterranean coast (Verlaque et al., 2003; Piazzi et al., 2005) and has become known as one of the most notorious and aggressive invaders of recent decades (Streftaris and Zenetos, 2006). In the colonized sites the alga is able to develop high biomasses over different substrate types, constraining the diversity of native benthic assemblages (Argyrou et al., 1999; Piazzi et al., 2001; Balata et al., 2004; Piazzi and Balatta, 2008; Vázquez-Luis et al., 2008; Klein and Verlaque, 2009).

While many studies have focused on spatial patterns and temporal dynamics of the distribution, phenology and biomass of $C$. racemosa, only a few have dealt with the potential competitive mechanisms responsible for its ecological success in sublittoral Mediterranean environments (see Klein and Verlaque, 2008 for a review). Among other plant traits (e.g. vegetative and sexual reproductive success, production of allelopathic substances, physiological resistance to stress), morphological and physiological plasticity has been suggested as a likely adaptive feature enabling acclimation to a wide range of environmental conditions in this (Klein and Verlaque, 2008) and other C. racemosa varieties (Peterson, 1972; Riechert and Dawes, 1986; Ohba et al., 1992). The capacity of the alga to photoacclimate to varying light regimes has special importance in this context, since $C$. racemosa has been shown to be able to develop down to $70 \mathrm{~m}$ depth (Klein and Verlaque, 2008), colonize the understory of macrophyte canopies (Cecherelli and Campo, 2002) and maintain biomass through time even during conditions of severe light limitation (e.g. deep populations in winter: Cebrian and Ballesteros, 2009). However, our knowledge of the photoacclimative capacity of Mediterranean populations of C. racemosa is sparse at best (Raniello et al., 2004, 2006). Raniello et al. (2004, 2006) reported interesting data showing how $C$. racemosa is able to re-organize its photosynthetic pigment system in response to varying light conditions caused by depth gradients, seagrass canopies, and daily and seasonal cycles. Regarding depth (Raniello et al., 2006), changes in pigment composition were thought to represent algal photoacclimation responses in order to optimize light capture (increase in $\alpha$ ) and photosynthetic performance (decrease in $E_{k}$ ) as light becomes limiting. These are common responses seen in some macroalgae species able to develop over broad depth gradients (Ramus et al., 1977; Markager and Sand-Jensen, 1992; Gómez et al., 1997; Johansson and Snoeijs, 2002). Nonetheless, the extent to which the ability of Mediterranean populations of $C$. racemosa to photoacclimate effectively is responsible for productivity and potential colonization success remains unknown.

In the present study we analyzed the phosynthetic responses of $C$. racemosa in order to assess the pattern of algal productivity along a depth gradient. To this end a carbon balance approach was taken, based on the numerical integration of photosynthesis vs irradiance ( $\mathrm{P}$ vs $\mathrm{E}$ ) models throughout continuous measurement of instantaneous irradiance recorded at the sea floor. This mechanistic approach has been previously demonstrated to provide reliable estimates of primary productivity in marine macrophytes (Matta and Chapman, 1991; Zimmerman et al., 1994). Photosynthesis and respiration rates of $C$. racemosa fronds, together with continuous irradiance field data, were measured at three different locations of contrasting depth and light on the coast of the Murcia Region of SE Spain, a part of the Spanish Mediterranean coast invaded by the alga since 2005 (Ruiz et al., 2011).

\section{MATERIALS AND METHODS}

\section{Study area}

The present study was performed at 3 sampling stations located at 3 separate locations at different depths on the coast of the Murcia Region of SE Spain: a shallow station (S, $11 \mathrm{~m}$, Isla Grosa; 37 $\left.43^{\prime} \mathrm{N}, 00^{\circ} 42^{\prime} \mathrm{E}\right)$, an intermediate station (I, $18 \mathrm{~m}$, Cabo Tiñoso; $37^{\circ} 32^{\prime} \mathrm{N}$, $\left.00^{\circ} 44^{\prime} \mathrm{E}\right)$ and a deep station (D, $26 \mathrm{~m}$, Calblanque; $\left.37^{\circ} 32^{\prime} \mathrm{N}, 1^{\circ} 07^{\prime} \mathrm{E}\right)$ (Fig. 1). These depths are representative of the current bathymetric range of $C$. racemosa on the Murcian coast (10-30 m, Ruiz et al., 2011). At the time of sampling, the selected stations were located in the most invaded areas (in terms of colonized surface area) of the Murcian coast, with the alga present at stations I and D since 2005 and at station S since 2006. The most commonly invaded benthic communities are the unvegetated sediments and photophilic macroalgal assemblages on hard substrates found at station $\mathrm{S}$ and the coastal detrital sediments found at stations I and D, the latter being dominated by rhodoliths.

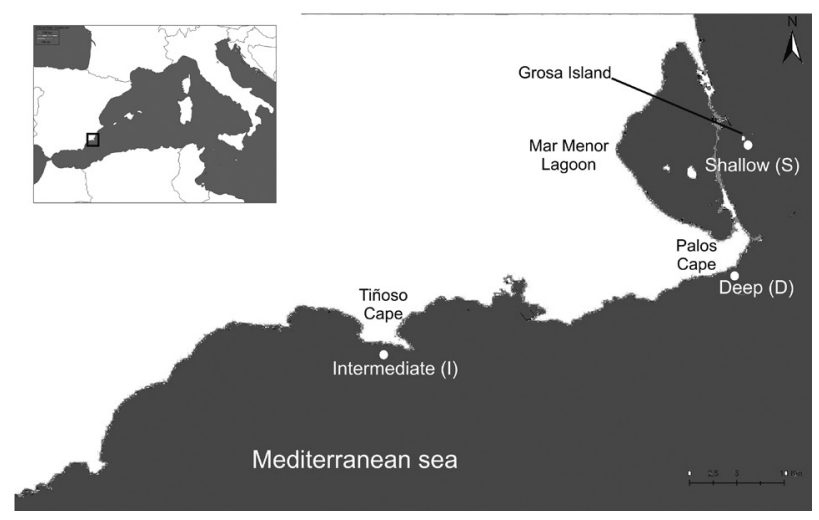

FIG. 1. - Location of sampling stations: shallow (-11 m, S), intermediate $(-18 \mathrm{~m}, \mathrm{I})$ and deep $(-26 \mathrm{~m}, \mathrm{D})$. 


\section{Field measurements: PAR irradiance and algal biomass}

All field work was performed by SCUBA divers at the end of summer (August 2008), a time of year in which the development of the alga is close to maximum in many areas of Murcia (personal observation) and other Mediterranean regions (Klein and Verlaque, 2008; but see Cebrian and Ballesteros, 2009). Incident irradiance on the sea floor was determined at each sampling station from continuous recording of instantaneous PAR irradiance (E, umol quanta $\mathrm{m}^{-2} \mathrm{~s}^{-1}$, 400-700 nm; Kirk, 1994), obtained via the deployment of a spherical $4 \pi$ quantum sensor (Alec Electronics, MDS MK5, Japan) for a period of 21 days (12 August to 1 September). All sensors were placed at a height of $5 \mathrm{~cm}$ from the sea floor. During the measuring period, the accumulation of epiphytes or particles on the sensor surface was observed to be negligible and no associated decline in incident light with time was observed. Quantum sensors were programmed to record at 10-minute intervals ( $\mathrm{n}=144$ measurements per day). A mean daily light cycle was obtained for each sampling station, characterized by maximum instantaneous irradiance at noon and the integrated daily irradiance (mol quanta $\mathrm{m}^{-2} \mathrm{~d}^{-1}$ ). In addition, measurement of subsurface instantaneous irradiance $\left(\mathrm{E}_{\mathrm{o}}\right)$ was performed at noon on 5 standard days (i.e. those with full sunlight, a cloudless sky and calm weather) using a flat, cosinecorrected $2 \pi$ sensor connected to a LI-COR quantum meter (model LI-190SA). Mean $\mathrm{E}_{\mathrm{o}}$ and noon instantaneous irradiance values measured at the sea floor on the same days were used to calculate both the percentage of $E_{o}$ reaching the seabed and the water-column attenuation coefficient $\left(\mathrm{K}_{\mathrm{d}}, \mathrm{m}^{-1}\right.$; Kirk, 1994) for each sampling station. Measurements of both sensor types were intercalibrated in the laboratory and showed a very strong linear relationship $\left(\mathrm{R}^{2}=0.998\right)$ with a constant factor of 1.176 .

At each sampling station, the abundance of $C$. racemosa was determined by measuring its total biomass (fronds, stolons and rhizoids) in six replicate quadrats of $400 \mathrm{~cm}^{2}$, randomly positioned within a surface area of $25 \mathrm{~m}^{2}$ colonized by the alga. Plant material of each sample was placed in dark plastic bags before being sorted, dried at $70^{\circ} \mathrm{C}(24 \mathrm{~h})$ and weighed for biomass quantification $\left(\mathrm{g} \mathrm{dw}^{-2}\right)$ in the laboratory.

\section{Measurement of photosynthesis and dark respiration rates}

Samples of C. racemosa collected at each station were transported to the laboratory in cooled and aerated containers for the measurement of photosynthetic and respiration rates and the determination of photosynthetic parameters. Prior to photosynthetic measurement, plants were held overnight in dark conditions and at a controlled temperature. Photosynthesis vs irradiance ( $\mathrm{P}$ vs $\mathrm{E}$ ) curves of $C$. racemosa assimilatory fronds were generated by following the incubation methods described by Walker (1985) and Cayabyab and Enríquez (2007). Photosynthetic and respiration rates were obtained by measuring oxygen flux evolution with a Clark-type $\mathrm{O}_{2}$ electrode installed in a DW3 chamber (Hansatech, UK) connected to a controlled temperature circulating bath. The incubation medium was filtered seawater at a temperature equal to that measured in the field during plant collection: $23^{\circ} \mathrm{C}$ for stations S and I and $18^{\circ} \mathrm{C}$ for station D. Dark respiration rate was calculated after an initial incubation interval of 15 min in darkness (initial $R_{d}$ ), with net oxygen production $(\mathrm{P})$ subsequently determined for 13 light levels of between 14 and $1500 \mathrm{mmol}_{\text {quanta }} \mathrm{m}^{-2}$ $\mathrm{s}^{-1}$ provided by an LS2 tungsten-halogen light source (Hansatech, UK). After exposure to the final level of light intensity, the frond was returned to darkness and the final dark respiration rate was determined (final $R_{d}$ ). No significant differences were found between initial and final respiration rates in any of the incubations performed. Four C. racemosa frond replicates of $c a .2$ $\mathrm{cm}$ length were incubated for each sampling station. Prior to incubations, $\mathrm{NaCO}_{3}$ was added to the incubation chamber up to a concentration of $5 \mathrm{mM}$ to prevent carbon limitation and $\mathrm{N}_{2}$ was bubbled into the water to maintain oxygen concentrations within a saturation range of $20-80 \%$.

Rates of oxygen flux were normalized to biomass (fresh weight, fw) and plotted against $\mathrm{E}$ values to construct the P vs E curve, from which the photosynthetic parameters were then derived. The maximum rate of net photosynthesis (net- $\mathrm{P}_{\max }$ ) was estimated by averaging the maximum $P$ values obtained at saturating irradiances, with gross photosynthesis (gross $\mathrm{P}_{\max }$ ) then obtained by adding $R_{d}$ to net- $P_{\max }$. Photosynthetic efficiency $(\alpha)$ was estimated from the slope of the regression line fitted to the initial linear part of the curve. The point of compensation irradiance $\left(\mathrm{E}_{\mathrm{c}}\right)$ was calculated as the intercept on the irradiance axis and the saturation irradiance $\left(\mathrm{E}_{\mathrm{k}}\right)$ as the quotient between a and net- $\mathrm{P}_{\max }$. Mean values of $E_{c}$ and $E_{k}$ obtained at each sampling station were then employed to calculate the lightcompensation $\left(\mathrm{H}_{\mathrm{c}}\right)$ and light-saturation $\left(\mathrm{H}_{\mathrm{k}}\right)$ periods, respectively, for each daily light curve obtained from continuous light measurement at the sea floor.

\section{Daily metabolic carbon balance}

For the calculation of sampling station carbon balance, the net photosynthetic rate $(\mathrm{P})$ was derived for each irradiance value of the entire light time series obtained for that station using the following MichaelisMenten function fitted to each P vs E data set:

$$
\mathrm{P}=\left[\text { gross } \mathrm{P}_{\max } \cdot \mathrm{E} /\left(\mathrm{E}+\mathrm{E}_{\mathrm{k}}\right)\right]+\mathrm{R}_{\mathrm{d}}(\text { Baly, 1935) }
$$

where gross $P_{\max }, E_{k}$ and $R_{d}$ are mean maximum gross photosynthesis, saturation irradiance and dark respiration rate obtained from the $\mathrm{P}$ vs $\mathrm{E}$ curves, respectively. 
This model is the best of a number of functions that have been previously found to fit well with P-E plots obtained for Caulerpa species (Gatusso and Jaubert, 1985; Chisholm and Jaubert, 1997). The accuracy of this application was evaluated by non-linear leastsquares regression at $95 \%$ probability (Sigma-Plot, Jandel Scientific). Daily net photosynthesis was obtained by numerical integration of calculated $P$ values over 24-h periods, before being transformed into equivalent carbon units (daily net $\mathrm{C}$ gain, $\mathrm{mg} \mathrm{C} \mathrm{g}^{-1} \mathrm{fw} \mathrm{d}^{-1}$ ) using the ratio $\mathrm{g} \mathrm{C}: \mathrm{g} \mathrm{O}_{2}=0.3$, assuming a photosynthetic quotient of 1.0 (Matta and Chapman, 1991; Rosenberg et al., 1995).

If photoacclimation does occur, the photoacclimation efficiency can be estimated as the proportion of daily net photosynthesis due to changes in photosynthetic parameters (Ruiz and Romero, 2001; Cayabyab and Enríquez, 2007). For this purpose, we considered that if photoacclimation does not occur at the deeper stations (I and D), then the P vs E curve obtained from these stations must be equal to that obtained for plants from the shallower station, S. Therefore, by integration of the $\mathrm{P}$ vs $\mathrm{E}$ curve from station $\mathrm{S}$ with light data from stations I and D, we can simulate the daily net photosynthesis that would be expected for plants from these deeper sites if photoacclimation did not occur. The photoacclimation efficiency can then be calculated as the relative percent difference between the simulated values and the real values, which were previously obtained using the respective $\mathrm{P}$ vs $\mathrm{E}$ curves.

\section{Data analysis}

A one-way ANOVA (Quinn and Keough, 2002) was used to assess the significance of differences in irradiance, algal biomass and photosynthetic parameters between sampling depths. Prior to this, data were transformed when the assumption of homoscedasticity was not fulfilled. A post-hoc multiple pairwise comparison of means, the Student-Newman-Keuls test (SNK; Quinn and Keough, 2002), was used when ANOVA revealed significant differences between depths. All significant effects were tested at a probability level of $P=0.05$.

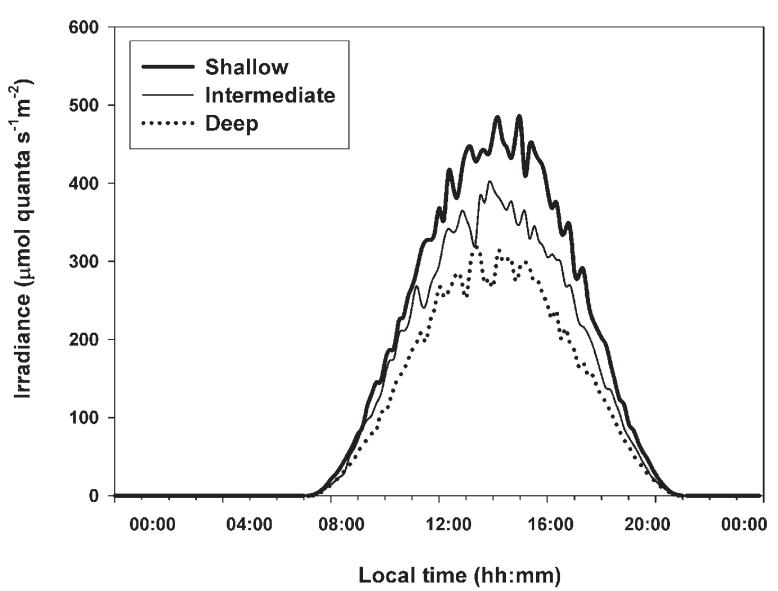

FIG. 2. - Daily variation in sea floor irradiance at each sampling station. Data are presented as the average of $21 \mathrm{~d}$ (see methods section). These curves were used to estimate the daily period of light saturation $\left(\mathrm{H}_{\mathrm{k}}\right)$ and compensation $\left(\mathrm{H}_{\mathrm{c}}\right)$ from saturation $\left(\mathrm{E}_{\mathrm{k}}\right)$ and compensation $\left(\mathrm{E}_{\mathrm{c}}\right)$ irradiances obtained in the $\mathrm{P}$ vs $\mathrm{E}$ curves (see Table 2).

\section{RESULTS}

The irradiance measurements of the studied stations showed a well-defined gradient related to depth (Fig. 2, Table 1). Relative to their mean value obtained at station S, both the noon instantaneous irradiance and the integral of daily irradiance decreased significantly at the other two stations: by $20 \%$ and $19 \%$, respectively, at station I and by $42 \%$ and $36 \%$ at station D (1-way ANOVA, $\mathrm{p}<0.05$; Table 1$)$. Both the mean noon subsurface irradiance $\left(\mathrm{E}_{\mathrm{o}}\right)$ and the water-column attenuation coefficient $\left(\mathrm{K}_{\mathrm{d}}\right)$ showed very similar values between sampling stations, with no significant differences being observed (Table 1). Mean noon instantaneous irradiance at the sea floor represented $33.6 \%, 26.2 \%$ and $21.6 \%$ of $\mathrm{E}_{\mathrm{o}}$ for stations $\mathrm{S}, \mathrm{I}$ and $\mathrm{D}$, respectively.

Total algal biomass showed significant differences between sampling depths ( $\mathrm{F}=8.3, P<0.05$; Fig. 3). The highest mean value was obtained at the shallowest depth, station $\mathrm{S}\left(62.6 \pm 17.4 \mathrm{~g} \mathrm{dw} \mathrm{m}^{-2}\right)$, decreasing by $20 \%$ at station I $\left(49.7 \pm 8.5 \mathrm{~g} \mathrm{dw} \mathrm{m}^{-2}\right)$ and by $73 \%$ at station D $\left(16.9 \pm 2.9 \mathrm{~g} \mathrm{dw} \mathrm{m}^{-2}\right)$.

TABLE 1. - Summary of irradiance measurements at each sampling station, determined from continuous light measurement at the sea floor during a 21 day period (i.e. daily light curves; Fig. 2) and instantaneous irradiance just below the surface measured at noon on standard sunny days $(\mathrm{n}=5)$. Data are presented as means \pm standard error. $\mathrm{MS}=$ means squares, $\mathrm{F}=\mathrm{F}$ statistic, $* \mathrm{P}<0.05, * * \mathrm{P}<0.01$, n.s. $=$ not significant.

\begin{tabular}{|c|c|c|c|c|c|}
\hline \multirow[b]{2}{*}{ Measurement: } & \multicolumn{3}{|c|}{ Sampling station } & \multicolumn{2}{|c|}{ One-way ANOVA } \\
\hline & $\mathrm{S}(-11 \mathrm{~m})$ & $\mathrm{I}(-18 \mathrm{~m})$ & $\mathrm{D}(-26 \mathrm{~m})$ & MS & $\mathrm{F}$ \\
\hline \multicolumn{6}{|l|}{ Daily light curves at sea floor: } \\
\hline $\begin{array}{l}\text { Noon instantaneous irradiance } \\
\left(\mu \mathrm{mol} \text { quanta } \mathrm{m}^{-2} \mathrm{~s}^{-1}\right)\end{array}$ & $442 \pm 28$ & $354 \pm 21$ & $254 \pm 17$ & 40686 & $146.86 * *$ \\
\hline 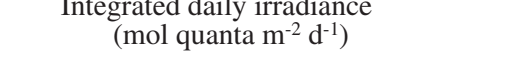 & $11.74 \pm 0.56$ & $9.47 \pm 0.30$ & $7.52 \pm 0.24$ & 0.047 & $19.56 * *$ \\
\hline \multicolumn{6}{|l|}{ Sub-surface irradiance: } \\
\hline $\begin{array}{c}\mathrm{E}_{\mathrm{o}}\left(\mu \mathrm{mol} \text { quanta } \mathrm{m}^{-2} \mathrm{~s}^{-1}\right) \\
\text { Water-column attenuation coefficient }\end{array}$ & $1710 \pm 78$ & $1677 \pm 224$ & $1659 \pm 219$ & 42432 & 0.44 n.s. \\
\hline $\begin{array}{l}\mathrm{K}_{\mathrm{d}}\left(\mathrm{m}^{-1}\right) \\
\% \mathrm{E}_{\mathrm{o}}\end{array}$ & $\begin{array}{c}0.098 \pm 0.01 \\
36.68\end{array}$ & $\begin{array}{l}0.082 \pm 0.01 \\
26.24\end{array}$ & $\begin{array}{l}0.095 \pm 0.01 \\
21.6\end{array}$ & $\begin{array}{c}0.000007 \\
-\end{array}$ & $\begin{array}{c}0.25 \mathrm{n} . \mathrm{s} . \\
-\end{array}$ \\
\hline
\end{tabular}




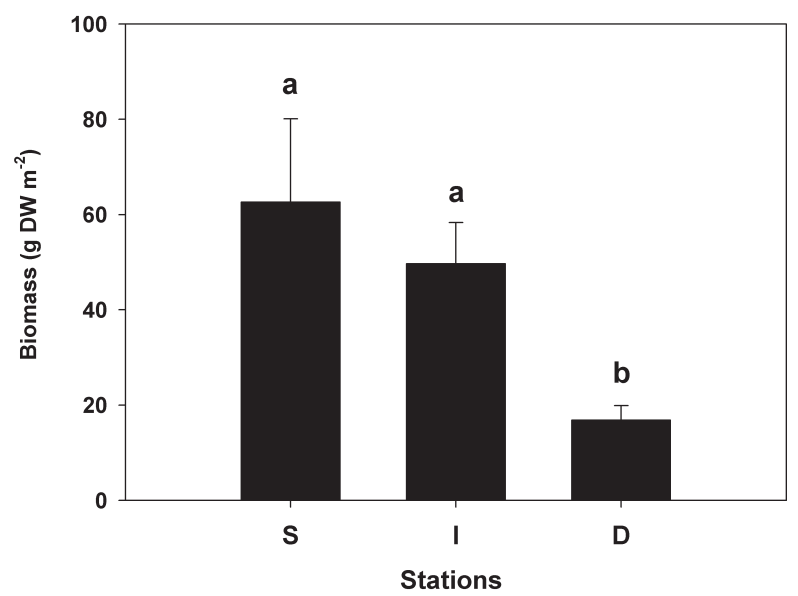

FIG. 3. - Total biomass ( $\mathrm{g} \mathrm{DW} \mathrm{m}^{-2}$ ) of $C$. racemosa at each sampling station. Data are presented as means and standard errors $(n=6)$. Different letters indicate groups of homogeneous means obtained in the post-hoc test $\operatorname{SNK}(P<0.05)$.

The P vs E curves of $C$. racemosa fronds obtained at each station are presented in Figure 4, with mean values of the photosynthetic parameters summarized in Table 2. All photosynthetic parameters showed significant variation between sampling depths. Mean net and gross $\mathrm{P}_{\max }$ and $\mathrm{E}_{\mathrm{k}}$ showed a substantial and significant decrease with depth, although no significant differences were found between mean values of these parameters at stations I and D (SNK, $P>0.05)$, which were significantly lower than those obtained at station $\mathrm{S}$ (Table 2).

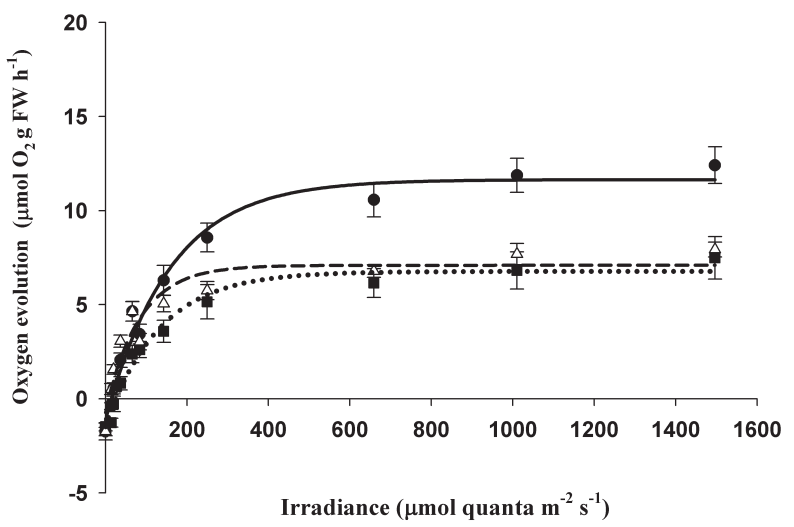

FIG. 4. - Photosynthesis vs irradiance (P vs E) curves determined from $C$. racemosa fronds at sampling stations $\mathrm{S}$ (full circles), I (full squares) and D (empty triangles). Points are means \pm SE $(n=4)$. The solid line represents the curve model fitted to experimental data (see methods section).

These differences were greater for station $\mathrm{D}$ (38\% for net $\mathrm{P}_{\max }, 37 \%$ for gross $\mathrm{P}_{\max }$ and $57 \%$ for $\mathrm{E}_{\mathrm{k}}$ ) than for station I (28\%, 25\% and 38\%, respectively). A similar general pattern was found for $R_{d}$ and $E_{c}$, but here the significant differences were caused only by the low mean values of these parameters obtained at station $\mathrm{D}$, which were both $\mathrm{ca}$. 33\% lower than those obtained at stations $\mathrm{S}$ and I. This variation in mean photosynthetic and respiration rates resulted in the gross $\mathrm{P}_{\max }: \mathrm{R}_{\mathrm{d}}$ ratios measured at stations I (6.25) and D (7.39) being very close to that obtained at station $\mathrm{S}$ (7.78). Photosyn-

TABle 2. - Photosynthetic parameters derived from P vs E curves and daily net carbon gain calculated for each sampling station. Data are presented as mean \pm standard error. Different letters indicate groups of homogeneous means obtained in the post-hoc test SNK $(\mathrm{P}<0.05)$. MS $=$ means squares, $\mathrm{F}=\mathrm{F}$ statistic, ${ }^{*} \mathrm{P}<0.05$, $* * \mathrm{P}<0.01$. Mean values of $\mathrm{H}_{\mathrm{k}}, \mathrm{H}_{\mathrm{c}}$ and daily $\mathrm{C}$ gains calculated under the assumption of no photoacclimation are indicated in the lower part of the table, as well as the photoacclimation efficiency (see the Materials and Methods section).

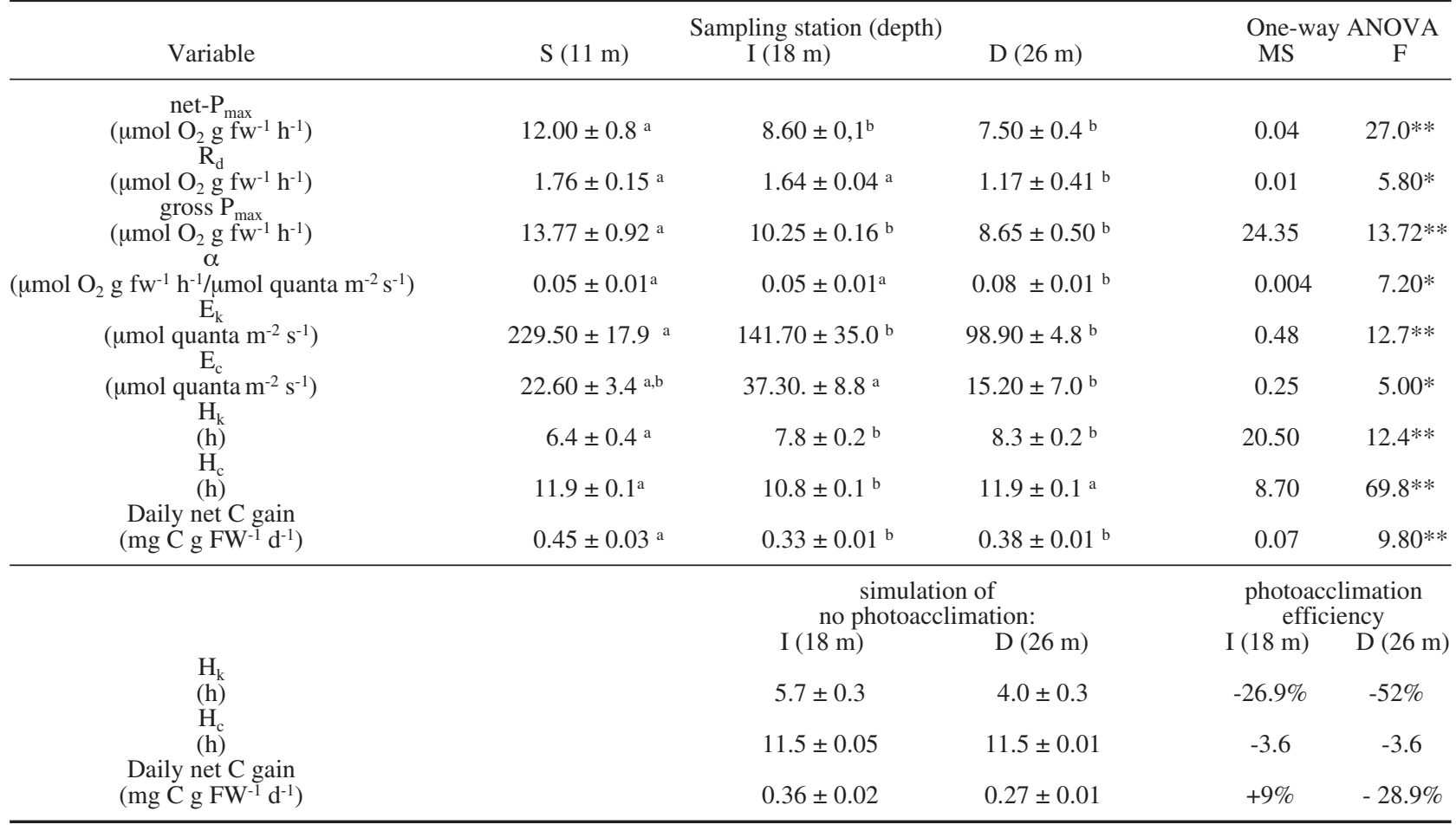


thetic efficiency $(\alpha)$ was significantly higher at station $\mathrm{D}$ than at the shallower two. The average daily periods of light compensation $\left(\mathrm{H}_{\mathrm{c}}\right)$ and saturation $\left(\mathrm{H}_{\mathrm{k}}\right)$ obtained by intercepting the mean $E_{c}$ and $E_{k}$ derived from the $P$ vs $E$ curves (Table 2) with the daily light curves (Fig. 2) are also shown in Table 2. While mean $\mathrm{H}_{\mathrm{c}}$ was quite similar at each sampling depth, mean $\mathrm{H}_{\mathrm{k}}$ showed a slight but significant increase with depth, with the absolute difference between stations $\mathrm{S}$ and $\mathrm{D}$ being almost 2 hours. The daily metabolic carbon balance was highly positive at all sampling depths, although the mean net $\mathrm{C}$ gain was $26 \%$ and $16 \%$ lower at stations I and D, respectively, relative to the mean values calculated for station $\mathrm{S}$ (Table 2). When considering a scenario of no photoacclimation (Table 2), the mean $\mathrm{H}_{\mathrm{c}}$ values of stations I and D were very similar to those obtained via their respective P-E models. However mean $\mathrm{H}_{\mathrm{k}}$ values recalculated at these stations were $c a$. $27 \%$ and $52 \%$ lower, respectively. The mean daily net $\mathrm{C}$ gain calculated for station I under the assumption of no photoacclimation was similar to that obtained using the P-E model for this station, but was $c a$. 29\% lower at station D.

\section{DISCUSSION}

Photosynthetic responses observed along the studied depth gradient essentially consisted of: a) an increase in photosynthetic efficiency at sub-saturating irradiances $(\alpha)$; b) a decrease in the maximum photosynthetic rates at saturating irradiances (gross- and net- $\mathrm{P}_{\max }$ ); and c) a reduction of the respiratory demand $\left(\mathrm{R}_{\mathrm{d}}\right)$. Clearly, the simplicity of the sampling design employed in this study (i.e. a comparison between the three, single sampling sites) precludes interpretation of the reported photosynthetic behaviour of C. racemosa across sampling depths exclusively in terms of photoacclimation. In fact, despite the clear pattern of light reduction (Fig. 2 and Table 1), other local factors not controlled by the experimental design can also vary with depth and influence photosynthetic performance. However, the photosynthetic responses observed in this study are in good agreement with general metabolic strategies used by sublittoral macroalgae to optimize light use and productivity under variable light conditions (Markager and Sand-Jensen, 1992; Kirk, 1994; Pérez-Lloréns et al., 1996; Gómez et al., 1997; Lobban and Harrison, 1997; Gómez, 2001). Furthermore, our results are highly consistent with differences in photosynthetic behaviour reported by other studied Mediterranean populations of $C$. racemosa between shallow and deep habitats (Raniello et al., 2006). Importantly, the authors of these studies also interpreted there results as being due to photoacclimation.

The pattern of variation of photosynthetic parameters was not uniform between sampling depths. The decline in photosynthetic rates (net and gross $\mathrm{P}_{\max }$ ) and $E_{k}$ represents the most significant photosynthetic response of fronds at the intermediate depth (I, $18 \mathrm{~m}$ ).
No further decline in photosynthetic rate was observed at the deepest station (D, $26 \mathrm{~m})$, but the lowest light requirements ( $\mathrm{E}_{\mathrm{k}}$ and $\mathrm{E}_{\mathrm{c}}$ mean values) were recorded here. This is likely due to the increase in photosynthetic efficiency $(\alpha)$ and the decrease in respiration activity $\left(\mathrm{R}_{\mathrm{d}}\right)$, both considered clear adaptations for the growth and survival of macroalgae under limiting light conditions (Markager and Sand-Jensen, 1992; Gómez, 2001).

Higher photosynthetic efficiencies $(\alpha)$ is a common feature of macroalgae to reduce light requirements for photosynthesis in low light environments and is usually achieved through adjustment of light-harvesting pigments, i.e. the size of the absorption cross-section (Gómez et al., 1997; Lobban and Harrison, 1997; Falkowski and Raven, 2007). Accordingly, high ratios of both chlorophyll $b$ and siphonaxanthin to chlorophyll $a$ have been reported for a number of Caulerpa species living in deep-water environments (Yokohama and Misonou, 1980; Riechert and Dawes, 1986; Williams and Dennison, 1990; Raniello et al., 2006), although no changes in $\alpha$ and pigment contents were found for the other Mediterranean invader $C$. taxifolia across a depth range similar to that of this study (Chisholm and Jaubert, 1997). Studying a Mediterranean C. racemosa population, Raniello et al. (2006) found increased concentrations of these accessory pigments with depth parallel to an increase in $\alpha$ and a decline in $\mathrm{E}_{\mathrm{k}}$ derived from ETR curves, which is consistent with the photosynthetic behaviour of the alga reported in this study for the deepest station (D) using P vs E curves. All this evidence suggests that the plasticity of $\alpha$ can be an important photoacclimatory mechanism of $C$. racemosa to cope with light reduction with depth.

A low respiration rate is also considered a common strategy to minimize light requirements and carbon losses in macroalgal species growing in deepwater habitats (Littler et al., 1986; Markager and Sand-Jensen, 1992; Gómez et al., 1997; Johanson and Snoeijs, 2002). In our study, the reduced dark respiration observed at the station $\mathrm{D}$ enabled net- $\mathrm{P}_{\max }$ and the $P: R_{d}$ ratio to be maintained at levels similar to those observed at station I. This reduction in dark respiration has not been previously documented in Mediterranean populations of $C$. racemosa, although it is consistent with that observed in a tropical variety of $C$. racemosa across a similar depth gradient (C. racemosa var $u v$ ifera; Riechert and Dawes, 1986). The lower ambient temperature at station $\mathrm{D}\left(18^{\circ} \mathrm{C}\right)$ than at station $\mathrm{I}\left(21^{\circ} \mathrm{C}\right)$ could also have contributed to the decrease in respiratory activity (e.g. Terrados and Ros, 1992). However, previous experimental evidence for this and other varieties of C. racemosa (Gattuso and Jaubert, 1985; Flagella et al., 2008) indicates a low sensitivity of $R_{d}$ to this factor within this narrow temperature range. Similarly, plants of the congeneric $C$. taxifolia collected in summer showed very constant dark respiration rates when incubated across the temperature range between 15 and $25^{\circ} \mathrm{C}$ (Gacia et al., 1996). Thus, reduction in metabolic 
demands could effectively reflect a strategy of the alga to maximize carbon gains under more limiting light conditions.

The photosynthetic responses reported in this study support the hypothesis that photosynthetic plasticity may be an important mechanism accounting for the success of $C$. racemosa across the depth gradients found in Mediterranean coastal waters (Raniello et al., 2006), and that this can be achieved through optimization of carbon fixation as light becomes more limiting (Markager and Sand-Jensen, 1992; Markager and Sand-Jensen, 1994; Gómez, 2001). Carbon balance calculations support this hypothesis for the studied C. racemosa populations. At station I, reductions in incident light and daily net productivity were similar in magnitude (28\% and $26 \%$, respectively, relative to station S). However, at station D, where the light reduction is greater $(41 \%)$, the daily net $\mathrm{C}$ gain was only $15 \%$ lower than that estimated for the station $\mathrm{S}$. This result can only be explained by reduced light requirements and respiratory losses (and higher photosynthetic efficiency) in C. racemosa fronds from the deepest population, which yielded mean $\mathrm{P}: \mathrm{R}$ ratios and $\mathrm{H}_{\mathrm{k}}$ and $\mathrm{H}_{\mathrm{c}}$ periods very close to (or even higher than) those obtained for station S. In the absence of photoacclimation, $\mathrm{H}_{\mathrm{k}}$ values should be considerably shorter (4 h) and metabolic carbon balance $c a .29 \%$ lower than the values actually measured in fronds from station D. Therefore, the reported photosynthetic responses effectively resulted in an optimization of $C$. racemosa productivity at the deepest site.

In conclusion, our results provide evidence supporting the capacity of $C$. racemosa to cope with changes in the light regime caused by depth variations through photosynthetic adjustments. Furthermore, this coping mechanism enables deep-water $C$. racemosa populations to achieve positive carbon balances close to those quantified for shallower populations, at least during a period of the year when growth conditions are optimal (i.e. late summer, see for example Ruitton et al., 2005). However, generalization of this conclusion must be made with caution until it is confirmed by similar studies at broader spatial and temporal scales. Other questions arising from our results should also be addressed by further future research. For example, the lower respiration rates observed for $C$. racemosa fronds at station D suggest reduced growth rates at this depth (Gómez, 2001), which would allow carbon storage to support algal growth and biomass under situations of severe light limitation in these deeper waters, such as during the winter. Although evidence for this metabolic adaptation has been reported in Caulerpa species (Robledo and Freile-Pelegrín, 2005), and has been suggested for macroalgae species which display negative carbon balances in winter (see Dunton and Shell, 1986; Gómez, 2001), this metabolic adaptation has not yet been demonstrated for Mediterranean $C$. racemosa populations. Moreover, the existence of such adaptive mechanisms could limit the capacity of this species to accumulate biomass in deep assemblages (as suggested by the lower algal abundance measured at station D). Much more research is necessary to determine which factor(s) are responsible for uncoupling $C$. racemosa net productivity and biomass. In particular, attention must be paid to the multiple environmental (abiotic and biotic) factors that can influence vertical patterns of algal abundance (Piazzi et al., 2001; Ruitton et al., 2005, 2006; Bulleri and Benedetti-Cecchi, 2008; Cebrian and Ballesteros, 2009; Klein and Verlaque, 2008, 2009; Tomas et al., 2011), as well as the annual carbon balance of the algae.

\section{ACKNOWLEDGEMENTS}

This research was funded by the Servicio de Pesca y Acuicultura de la Comunidad Autónoma de Murcia, the European Fisheries Fund and a research grant awarded to J Bernardeau-Esteller by the University of Alicante. We express our gratitude to Rocío GarcíaMuñoz for her valuable help in field and laboratory work. The authors are also thankful for the logistical support provided by the Servicio de Reservas Marinas (Ministerio de Medio Ambiente y Medio Rural y Marino) and the Servicio de Pesca y Acuicultura and Servicio de Protección y Conservación de la Naturaleza (Comunidad Autónoma de la Región de Murcia) which enabled field sampling to take place in the Cabo de Palos-Islas Hormigas Marine Reserve, Cabo Tiñoso and in the special protected area of Isla Grosa (ZEPA ES0000200 Isla Grosa).

\section{REFERENCES}

Argyrou, M., A. Demetropoulos and M. Hadjichristophorou. 1999. Expansion of the macroalga Caulerpa racemosa and changes in softbottom macrofaunal assemblages in Moni Bay, Cyprus. Oceanol. Acta, 22: 517-528.

Balata, D., L. Piazzi and F. Cinelli. - 2004. A comparison among assemblages in areas invaded by Caulerpa taxifolia and Caulerpa racemosa on a subtidal Mediterranean rocky bottom. Mar. Ecol., 25(1): 1-13.

Baly, E.C.C. - 1935. The kinetics of photosynthesis. Proc. R. Soc. Lond. Ser. B Biol. Sci., 117: 218-239.

Boudouresque, C.F. and M. Verlaque .-2002. Biological pollution in the Mediterranean Sea: invasive versus introduced macrophytes. Mar. Poll. Bull., 44: 32-38.

Bulleri, F. and L. Benedetti-Cecchi. - 2008. Facilitation of the introduced green alga Caulerpa racemosa by resident algal turfs: experimental evaluation of underlying mechanisms. Mar. Ecol. Prog. Ser., 364: 77-86.

Cayabyab, N.M. and S. Enríquez. - 2007. Leaf photoacclimatory responses of the tropical seagrass Thalassia testudinum under mesocosm conditions: a mechanistic scaling-up study. New Phytol., 176: 108-123.

Cebrian, E. and E. Ballesteros. - 2009. Temporal and spatial variability in shallow and deep water populations of the invasive Caulerpa racemosa var. cylindracea in the western Mediterranean. Estuar. Coast. Shelf Sci., 83: 469-474.

Cecherelli, G. and D. Campo. - 2002. Different effects of Caulerpa racemosa on two co-ocurring seagrasses in the Mediterranean. Bot. Mar., 45: 71-76.

Chisholm, J.R.M. and J.M. Jaubert. - 1997. Photoautotrophic metabolism of Caulerpa taxifolia (Chlorophyta) in the NW Mediterranean. Mar. Ecol. Prog. Ser., 153: 113-123.

Dunton, K.H. and D.M. Shell. - 1986. Seasonal carbon budget and 
growth of Laminaria solidungula in the Alaskan High Artic. Mar. Ecol. Prog. Ser., 31: 57-66.

Falkowski, P.G. and J.A. Raven. - 1997. Aquatic photosynthesis. Blackwell Scientific Publishers, Oxford.

Flagella, M.M., M. Lorenti and M.C. Buia. - 2008. Temperature response in a shallow-water Mediterranean population of Caulerpa racemosa var. cylindracea (Caulerpales, Chloropyta), and a possible strategy of season anticipation. Bot. Mar., 51(4): 278-284.

Gacia, E., C. Rodríguez-Prieto, O. Delgado and E. Ballesteros. 1996. Seasonal light and temperature responses of Caulerpa taxifolia from northwestern Mediterranean. Aquat. Bot., 53: 215-225.

Gatusso, J.P. and J. Jaubert. - 1985. Photosynthesis and respiration of Caulerpa racemosa (Chlorophyceae, Caulerpales) grown in aquaria: Effects of light and temperature. Bot. Mar., 28: 327-332.

Gómez, I., G. Weykam, H. Klöser and C. Wiencke. - 1997. Photosynthetic light requirements, metabolic carbon balance and zonation of sublittoral macroalgae from King George Island (Antarctica). Mar. Ecol. Prog. Ser., 148: 281-293.

Gómez, I. - 2001. Ecophysiology of antartic macroalgae: effects of environmental light conditions on photosynthetic metabolism. Rev. Chil. Hist. Nat., 74: 251-271.

Johansson, G. and P. Snoeijs. - 2002. Macroalgal photosynthetic responses to light in relation to thallus morphology and depth zonation. Mar. Ecol. Prog. Ser., 244: 63-72.

Kirk, J.T. - 1994. Light and Photosynthesis in Aquatic Ecosystems. Cambrige University Press. Cambridge. Klein, J. and M. Verlaque. - 2008. The Caulerpa racemosa invasion. A critical review. Mar. Poll. Bull., 56: 205-225.

Klein, J.and M. Verlaque. - 2009. Macroalgal assemblages of disturbed coastal detritic bottoms subject to invasive species. Estuar. Coast. Shelf Sci., 82: 461-468.

Littler, M.M., D.S. Littler, S.M. Blair and J.N. Norris. - 1986. Deepwater plant communities from an unchartered seamount off San Salvador Island, Bahamas: distribution, abundance and primary productivity. Deep-Sea Res., I 33: 881-892.

Lobban, C.S. and P.J. Harrison. - 1997. Seaweed ecology and physiology. Cambridge University Press, Cambridge.

Matta, J.L. and D.J.Chapman. - 1991. Photosynthetic responses and daily carbon balance of Colpomenia peregrina: seasonal variations and differences between intertidal and subtidal populations. Mar. Biol., 108: 303-313.

Markager, S. and K. Sand-Jensen. - 1992. Light requirements and depth zonation of marine macroalgae. Mar. Ecol. Prog. Ser., 88: 83-92.

Markager, S. and K. Sand-Jensen. - 1994. The physiology and ecology of light-growth relationships in macroalgae. In: F.E. Round and D.J. Chapman (eds.), Progress in Phycological Research, pp. 209-298. Biopress, Bristol.

Ohba, H., H. Nashima and S. Enomoto. - 1992. Culture studies on Caulerpa (Caulerpales, Chlorophyceae) III. Reproduction, development and morphological variation of laboratory-cultured C. racemosa var. peltata. Bot. Mag. Tok., 105: 589-600.

Pérez-Lloréns, J.L., J.J. Vergara, R.R. Pino, I. Hernández, G. Peralta and F.X. Niell. - 1996. The effect of photoacclimation on the photosynthetic physiology of Ulva curvata and Ulva rotundata (Ulvales, Chlorophyta). Eur. J. Phycol., 31: 349-359.

Peterson, R.D. - 1972. Effects of light intensity on the morphology and productivity of Caulerpa racemosa (Forskål) J. Agardh. Micronesica, 8: 63-86.

Piazzi, L., G. Cecherelli. and F. Cinelli. - 2001. Threat to macroalgal diversity: effects of the introduced green alga Caulerpa racemosa in the Mediterranean. Mar. Ecol. Prog. Ser., 210: 149-159.

Piazzi, L., A. Meinesz and M. Verlaque. - 2005. Invasion of Caulerpa racemosa var. cylindracea (Caulerpales, Chlorophyta) in the Mediterranean Sea: an assessment of the spread. Cryptog. Algol., 26: 189-202.

Piazzi, L. and D. Balata. - 2008. The spread of Caulerpa racemosa var. cylindracea in the Mediterranean Sea: An example of how biological invasions can influence beta diversity. Mar. Environ. Res., 65: 50-61.

Quinn, G.P. and M.J. Keough. - 2002. Experimental designs and data analysis for biologists. Cambridge University Press,
Cambridge.

Ramus, J., F. Lemons and C. Zimmerman. - 1977. Adaptation of light-harvesting pigments to downwelling light and the consequent photosynthetic performance of the eulittoral rockweeds Ascophyllum nodosum and Fucus vesiculosus . Mar. Biol., 42(4): 293-303.

Raniello, R., M. Lorenti, C. Brunet and M.C. Buia. - 2004. Photosynthetic plasticity of an invasive variety of Caulerpa racemosa in a coastal Mediterranean area: light harvesting capacity and seasonal acclimatation. Mar. Ecol. Prog. Ser., 271: 113-120.

Raniello, R., M. Lorenti, C. Brunet and M.C. Buia. - 2006. Photoacclimation of the invasive alga Caulerpa racemosa var. cylindracea to depth and daylight patterns and a putative new role for siphonaxanthin. Mar. Ecol., 27: 20-30.

Riechert, R. and C.J. Dawes. - 1986. Acclimation of the green alga Caulerpa racemosa var. uvifera to light. Bot. Mar., 29: 533-537.

Robledo, D. and Y. Freile-Pelegrín. - 2005. Seasonal variations in photosynthesis and biochemical composition of Caulerpa spp (Bryopsidales, Chlorophyta) from the Gulf of Mexico. Phycologia, 44: 312-319.

Rosenberg, G., D.S. Littler, M.M. Littler and C. Oliveira. - 1995. Primary production and photosynthetic quotients of seaweeds from Sao Paulo State, Brazil. Bot. Mar., 38: 369-377.

Ruitton, S., M. Verlaque and C.F. Boudouresque. - 2005. Seasonal changes of the introduced Caulerpa racemosa var. cylindracea (Caulerpales, Chlorophyta) at the northwest limit of its Mediterranean range. Aquat. Bot. 82: 55-70.

Ruitton, S., M. Verlaque, G. Aubin and C.F. Boudouresque. - 2006. Grazing on Caulerpa racemosa var. cylindracea (Caulerpales, Chlorophyta) in the Mediterranean Sea by herbivorous fishes and sea urchins. Vie Milieu, 56: 33-41.

Ruiz, J.M. and J. Romero. - 2001. Effects of in situ experimental shading on the Mediterranean seagrass Posidonia oceanica. Mar. Ecol. Prog. Ser., 215: 107-120.

Ruiz, J.M., L. Marín-Guirao, J. Bernardeau-Esteller, A. RamosSegura, R. García-Muñoz and J.M. Sandoval-Gil. - 2011. Spread of the invasive alga Caulerpa racemosa var. cylindracea (Caulerpales, Chlorophyta) along the Mediterranean coast of the Murcia Region (SE Spain). Anim. Bio. Cons., 34: 73-82.

Terrados, J. and J.D. Ros. - 1992. The influence of temperature on seasonal variation of Caulerpa prolifera (Forsskal) Lamouroux photosynthesis and respiration. J. Exp. Mar. Biol. Ecol., 162: 199-212.

Tomas, F., E. Cebrian and E. Ballesteros. - 2011. Differential herbivory of invasive algae by native fish in the Mediterranean Sea. Estuar. Coast. Shelf Sci., 92: 27-34.

Streftaris, N. and A. Zenetos. - 2006. Alien Marine Species in the Mediterranean - the 100 'Worst Invasives' and their impact. Medit. Mar. Sci., 7(1): 87-118.

Vázquez-Luis, M., P. Sánchez-Jerez and J.T. Bayle-Sempere. 2008. Changes in amphipod (Crustacea) assemblages associated with shallow-water algal habitats invaded by Caulerpa racemosa var. cylindracea in the western Mediterranean Sea. Mar. Environ. Res., 65: 416-426

Verlaque, M., C. Durand, J.M. Huisman, C.F. Boudouresque and Y. Le Parco. - 2003. On the identity and origin of the Mediterranean invasive Caulerpa racemosa (Caulerpales, Chlorophyta). Eur. J. Phycol., 38: 325-339.

Walker, D.A. - 1985. Measurement of oxygen and chlorophyll fluorescence. In: J. Coombs, D.O. Hall, S.P. Long and J.M.O. Scurlock (eds.), Techniques in bioproductivity and photosynthesis. Pergamon Press, Oxford.

Williams, S.L. and W.C. Dennison. - 1990. Light availability and diurnal growth of a green macroalga (Caulerpa cupressoides) and a seagrass (Halophila decipiens). Mar. Biol., 196: 437-443.

Yokohama, Y. and T. Misonou. - 1980. Chlorophyll $a: b$ ratios in marine benthic algae. Jap. J. Phycol., 28: 219-223.

Zimmerman, R.C., A. Capello-Pasini and R.S. Alberte. - 1994. Modeling daily production of aquatic macrophytes from irradiance measurements: a comparative analysis. Mar. Ecol. Prog. Ser., 114: 185-196.

Scient. ed.: E. Ballesteros.

Received December 10, 2010. Accepted April 5, 2011.

Published online October 17, 2011. 